\title{
Physicist-turned-ecologist to take top UK advisory post
}

London. Last Monday - the day after England beat Australia in the rugby world cup - John Major, the British prime minister, redressed the balance by announcing the appointment of Robert May, an Australian-born physicist turned mathematical ecologist, as his chief scientific adviser.

May, who is currently Royal Society research professor at the University of Oxford and Imperial College, London, will succeed Sir William Stewart in a post which also includes responsibilities as head of the Office of Science and Technology.

A combative and frequently outspoken researcher, May is widely known for a keen intellect which can occasionally seem impatient with those promoting ideas that cannot be backed by persuasive quantitative arguments.

But he is also known as a dedicated researcher with unusually broad academic interests, and as an individual who has taken an active interest in issues ranging from career structures for young scientists, to the scientific basis of preserving biodiversity.

"I think it is an excellent appointment. Bob is an individual who can think quickly on his feet and knows his own mind, and is also firmly in touch with the issues facing the scientific community," says one of his academic colleagues.

May, who is 59, was born in Sydney, where he gained a $\mathrm{PhD}$ in theoretical physics. He taught at Sydney University from 1962 to 1973, when he was appointed professor of biology - and later Class of 1877 Professor of Zoology - at the University of Princeton.

It was over this period that he turned from physics to theoretical ecology. May says he "blundered into the golden age of mathematical biology", with a particular interest in topics such as the population biology of infectious diseases.

He now suggests that his scientific background may have provided him with skills that will stand him in good stead in his new post. "In my work, I tend to take a very complicated real-world situation, form a view of what is the most important thing going on, put it in precise terms, and then say: what have I learnt about the system as a whole?"

May gained experience in research administration as Princeton's vice-president for research, a position which carried responsibility for research policy and administration. As such, he says, he experienced "in some sense the same relation to the president of the university as the chief scientist does to the British prime minister."

Given that May has had relatively little direct involvement in conventional UK science policy circles - news of his possible appointment generated some surprise as a result (see Nature 374, 583; 1995) - his track record at Princeton may have weighed in his favour. May points out with some pride that during his term of office, he not only doubled the volume of research at the university, but increased "from 2 to 12 per cent" its income from industrial sponsors."

Since being appointed to his current post in 1988, May has become deeply involved in many topics at the intersection of biology and public policy. These range from debates over biodiversity - he was for a time a trustee of the World Wide Fund for Nature, and is currently chairman of the trustees of the Natural Histo-

ry Museum - to the epidemiology of AIDS.

His own intellectual interests have been closely concerned with the development of chaos theory and nonlinear dynamics, including their application application to May: supportive of

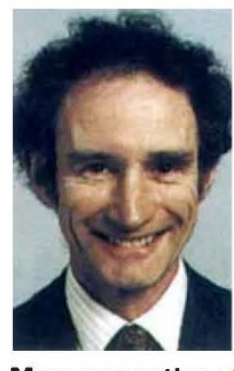
theoretical immunology to the behaviour of stock markets. May says that he hopes to be able to spend a small amount of his time to continuing such work. "It will give an added dimension and strength to my new job if I can remain actively engaged in experiments."

But he also has few illusions about the size of the task that he is taking on, with a portfolio that includes topics ranging from the continuation of the government's technology foresight exercise to the use of animals in experiments. May remains discreetly silent about his views on such topics. But he is full of praise for his predecessor. "I have the characteristic of saying what I fecl about things, and in this case, that is not too difficult," he says. "Bill Stewart has done a wonderful job."

Others suggest some of his likely priorities. "He is, for example, very supportive of young scientists, and keenly aware of the need for universities to put in place career structures for their researchers," says Roy Anderson, a fellow professor of zoology (and epidemiologist) at Oxford.

Another colleague claims that "there is a certain lack of numeracy in government, and I hope that Bob is able to redress the balance." Anderson describes May as "someone who always wants to confront theory with observation." His new post will provide him with ample opportunity to do so.

David Dickson
ESA science head warns of threat to future missions

Paris. Roger Bonnet, director of the space science programme of the European Space Agency (ESA), warned this week that future space missions may have to be delayed or cancelled if the United Kingdom insists on a 25 per cent reduction in the costs of the programme when Europe's space ministers meet in Toulouse in October.

Speaking at a press conference during the Paris air show, Bonnet said that if ministers approved cuts of such magnitude, there would be no "miracle solution", and ESA would be forced to delay by five years one of the 'cornerstone' missions - large missions budgeted to cost around ECU625 million (US\$825 million) - within the current Horizon 2000 programme.

Two possible candidates in such a scenario would be either the X-ray telescope XMM, which is scheduled for 1999 , or the Rosetta mission, due to be launched around 2003 with the aim of landing instruments on the surface of a comet around 2013.

Given the amount of work that has already gone into the first of these, Rosetta could be the more vulnerable. Bonnet adds that a five-year delay could make a mission scientifically uncompetitive, and it would probably be cancelled instead.

ESA had previously also hoped to obtain a four to five per cent increase in the budget of Horizon $2000+$, the science programme that will run for ten years from 2006, in order to pay for what would be the space agency's first venture into the field of fundamental physics.

This cornerstone mission would be aimed at detecting gravitational waves by launching six satellites millions of kilometres apart and keeping them connected by laser beams. Bonnet says that if the project is judged to be feasible, ESA will now look for "entrance fee" funding instead from the particle physics community.

Declan Butler

\section{Indian appointments}

New Delhi. India last week named Valangiman Ramamoorthy, a prominent physicist who is at present director of the Institute of Physics in Bhubaneswar, Orissa State, as head of the Department of Science and Technology. He replaces P. R. Rao, who retires later this month.

The government has also appointed a new director general for the Council of Scientific and Industrial Research, the country's main scientific agency with responsibility for more than 40 laboratories. Ragunath Mashelkar, a polymer scientist who trained in the United Kingdom, will take over from Shri Krishna Joshi, who is retiring on 1 July. 